\title{
REVIEW ARTICLE: Dworkin's Mercy
}

\author{
Roz Kaveney
}

\author{
Mercy \\ Andrea Dworkin \\ London: Secker 1990 \\ $£ 13.99$ hbk, ISBN 0436200139
}

Polemical novels are problematic, both ethically and aesthetically. When a novel is merely a novel, the aesthetic questions around it have to do with how well it achieves its artistic ends; a critic may prefer Alexandrian tricksiness, or may prefer simple passionate utterance, but these preferences are matters of opinion. When we are considering a polemic, the questions that have to be asked deal with the position advocated, but also with the methods adopted; most would agree that a polemic in favour of an egalitarian project which manipulates by subliminal rhetorical cues is devalued thereby, because to influence rather than to argue is to adopt a position of superiority at odds with the ideology promoted.

When a novel is both art object and argument, the weighing of the two sets of judgements becomes complex. The duty to produce the best possible novel, and the duty to put a case as clearly as possible in a way that respects readers' understanding, might sometimes conflict and have to be balanced. In this as in so much else, Andrea Dworkin makes it clear that she would like things to be simple -'I wanted some words; of beauty; of power; of truth; simple words; ones you could write down; to say some things that happened, in a simple way'. The bitingly satirical approach she takes, in her prologue and her epilogue, to an imagined postmodernist, libertarian, feminist opponent, makes it clear that she will have nothing to do with irony, or tricksiness or moral ambiguity. If we are to judge Mercy by Dworkin's own standards, we should expect it to be sensitive to both aesthetic and ethical approaches, not only in what it says, but in how it says it. 
Much has been claimed for Mercy, not least by its author. It weighs in as a leading contender for the title of Great Feminist Novel of our time; we are told that its failure to find a publisher in the United States is, as indeed it may be, the result of the conspiracy to suppress the thought of a leading feminist. It has to be said, without putting too much stress on the issue, that, in general, conspiracies to suppress are rather more successful; having most of one's work in print, and freely on sale, in one's native language, and regularly appearing on talk shows and in newspaper interviews is a sort of suppression to which many famous writers of the twentieth century might aspire, many political and sexual dissidents vainly desire. ${ }^{1}$ It has further to be said that, within the novel, which generally portrays the author as lone and embattled, the single oppositional voice heard is obliged to validate the protagonist's viewpoint by acknowledging 'Sexual Jacobins ... are sexualised in the common culture as if they are the potent women. Everyone pays attention to them ... Dworkin attributes this phrase to her opponent, but seems to accept the title with pride. Does she not know what the historical Jacobins did to the French feminists of the Revolutionary period?)

We are told, often by mainstream literary critics like Lorna Sage, that Dworkin is an 'essential' feminist writer because she writes with such passion about intolerable transgression; we will note, in passing, the assumption that feminist literature, and feminism itself, should be about feeling rather than thought, the further assumption that there is a division between those two and a choice to be made. (The abusive caricature of her feminist opponents offered in Dworkin's prologue and epilogue makes these assumptions a clear part of her own discourse her opponent is clearly, as they used to say in the Tory party, too clever by half.)

This prologue and epilogue aside, the novel offers us a series of monologues in chronological sequence, detailing the experiences of a protagonist who shares the author's name, but specific identity with whom the author has explicitly disavowed - 'I am not the person in the book'. This woman is sexually assaulted, sexually brutalized during treatment by prison doctors, sexually harassed, raped, subjected to wife battering, involved in nonconsensual fellatio and sado-masochism, and outraged by pornography. She aligns these experiences to her intuition that she partakes, perhaps by reincarnation, in the experience of the concentration camps; there is a long sequence in which the mass suicide of the Jewish zealots at Masada is at once praised and blamed, and an earlier avatar of the narrator kills herself so as to be a dissident participant in it. Her early involvement in the peace movement leads her to identify in an abstract sort of way with men who burned themselves alive to promote peace. She argues for an aesthetic and a politics that will concentrate on convicting men, and punishing them; to this end, the protagonist fire-bombs pornographers and beats up random members of the dispossessed substance-abusing urban male proletariat, hoping that this will inspire emulation. To heighten our 
emotional involvement, the book is written in long spans of declaratory sentences hitched on to each other with semi-colons; its monologue is rarely broken by speech.

Mercy is an ambitious novel, and its author's ambitions are clearly not merely literary. It has always seemed like gratuitous abuse to accuse Andrea Dworkin of Messianic fantasies, and most, if not all, of her opponents in the women's movement have accordingly refrained; this will no longer be necessary. One of the two epigraphs to the book is a quotation from Isaiah, about the imminent return of God as the redeemer; the endless Job-like rebukes to a God who is not absent, but rather a sadistic father, possibly make this ironic, but at various points Dworkin makes it clear that what she is describing is a Stations of the Cross. Her narrator's side is pierced, literally by an appendectomy operation, and later in a receiving of the stigmata; when she fantasizes about the killing of her ex-husband by anonymous women guerrillas, she uses the language of the Mass - 'for this; do this; for me' - to make it a sacramental participation in her redemptive acts. The protagonist's central insight - 'It is important for women to kill men' comes to her from 'a woman I didn't know with the face of an angel', and presumably an angel's origin and authority. This is a book which claims privilege at various points and in various ways; principal among those privileges is the claim to be regarded as a Holy Book, and thus as, if not truth, gospel.

Even though the author has disavowed specific identification with the protagonist, this is a novel which claims the special privilege which confessional has traditionally held in the women's movement; its first epigraph is from one of Sylvia Plath's most famous confessional poems. Even a naive reader knows that, beyond this text, the author has written other texts which offer an analysis of women's lot, based in part on personal experience, and specific programmes to combat sexual oppression; that naive reader would accordingly be entitled to assume that what is on offer here is analysis, experience and programme.

By disavowing specifically autobiographical intent here, Dworkin does not so much remove the implied authenticity of the personal, but add to it a claim of even more generalized authenticity; this is the biography either or at once of a fictional character, of Dworkin herself, or of Everywoman remade, by literary technique, in Dworkin's own image. One could choose to regard this as a postmodernist deconstruction of a particular feminist literary technique, but, given the specific denunciation of postmodernism in the text, it seems more likely that this is an old-fashioned matter of having one's cake and eating it. It might also, by the not especially naive reader, be taken as an abuse of the reader's sisterly trust.

One of the ways in which this is done is by an at times highly sophisticated, and at other times surprisingly crude, literary manipulativeness masquerading as demotic simplicity. Generally, this is a book which claims its moral superiority from its appearance of simplicity, and that authenticity which the appearance of simplicity often claims, but which achieves that appearance by constructing webs of technique. 
When Dworkin writes of childhood, she does so in a language of simple declaration, with much repetition, and many sentences that start with conjunctions and tag on to each other endlessly without puctuation.

and you don't know the right words but you try so hard and you say exactly how the man sat down and put his arm around you and started talking to you and you told him to go away but he kept holding you ...

This is not reportage of the actual language of an actual abused eight-year-old, but rather the use of a literary convention of representation of children's speech, itself based on assumptions about what a child is and what concepts a child is capable of forming. Innocence has a moral authority, which, according to magical thinking, can be appropriated by miming the surface of innocence.

There is a tradition in American literature, and demagoguery, of using contractions aggressively to demonstrate commitment to straightforward expression, ignoring effete correctness; this tradition has been adopted by much representation of street and black speech. When Andrea, the character, suddenly starts saying 'Ain't', as in 'Terror ain't aesthetic' or 'You may find me one who ain't guilty, but you can't find me two', it is this tradition, and the moral authority attached to it, which is being invoked. (When Andrea is mocking the idea that any SM porn could be a record of consensual acts, she invokes the struggle for black civil rights: 'If I saw pictures like that of a black man I would cry out for his freedom; I can't see how it's confusing if you ain't KKK.' Any dissent from the Dworkin line is straight complicity with fascism, it appears.)

Other examples of this appropriation have been referred to above in my synopsis, and it is worth citing at least one example in detail:

Birch trees make me feel sad and lonely and afraid. There's astrologers who say that if you were born when Pluto and Saturn were travelling together in Leo, from 1946 to about the middle of 1949, you died in one of the concentration camps and you came right back because you had to come back and set it right. Justice pushed you into a new womb and outrage, a blind fury, pushed you out of it onto this earth, this place, this zoo of sickness and sadists . . I consider Birkenau my birthplace.

At various points in the feminist debates around sado-masochism, some startling claims to moral authority were flung around, but for brazen cheek, and carelessness of offense to camp survivors, this appropriation of actual pain to literary effect takes the biscuit. ${ }^{2}$ It is also stunningly clumsy in its movement between the poetic, the pseudo-scientifically specific, the personified and the merely outrageous.

The book adopts magic-realist techniques freely; or, to put it another way, it complicates its realist description and analysis by incidents of doubtful likelihood. When one of Andrea's rapists kisses her 
body, his kisses open up as infected wounds; later in the book her unhealed wounds bleed the green of rot and corrosion. If these are to be taken as metaphors, which clearly they are, what are we to assume about the claim that fellatio has denatured the narrator's voice 'something hoarse and missing, an absence, a mere vibration' - is this a realist claim about physical injury, or a metaphysical claim about the loss of personal integrity and authenticity? In a text which is political and ethical as well as literary, we are entitled to know which; an author who is playing Prophet cannot also play Trickster.

On another occasion, Andrea protests against what has happened by setting herself on fire, by becoming flame; this is a metaphor for rage, and an appropriation of the moral authority of actual political suicides. What then of the narrator's fire-bombing of porn stores? Is this a political programme, or a prophesy, or another metaphor? Further, is this a complicated use of literary techniques in a way that brings out the ambivalences so loved by the postmodernism Dworkin ritually comminates, or is it a way of recommending illegal acts while avoiding charges of incitement?

The novel uses traditional Romantic sentimentality to an extent that is perhaps surprising, given the historic associations of that sentimentality with disempowering images of women. When Andrea consensually fellates a British taxi-driver, who proceeds to abuse the trust he has won by walking the dog she is too drunk to walk herself, by thrusting deep into her, she swoons; her pain and misery before and upon awakening from this swoon are heightened by the presence of the innocent and unknowing animal with 'its sweet melancholy look'. The streets of Andrea's passion are mean and neon-shiny and rain-swept; this is a book in which the pathetic fallacy is not only alive and well, but part of an implied claim that Andrea has, as Woman, the right to the overt sympathy of animals and the Weather.

The book sometimes makes eloquent, and intermittently effective, use of the graphically unpleasant, but more often places a screen of abstraction between what is shown and what is being described. The aforementioned swoon is not the only one of its kind in the book; Dworkin ritually denounces Sade, but has learned from him the teasing avoidance of the specific in descriptions of the sexual act that a heroine's momentary unconsciousness affords. Dworkin uses the word 'pain' a lot, but rarely, save through extravagant metaphors, is that pain described or made specific and concrete. The act of fellatio, for example, is described as disgusting on the ground that it is like the man trying to kill a small furry animal in your throat, or because DNA from his semen is colonizing your brain; we find oddly little here about the more obviously unpleasant aspects of oral-penile contact - the presence of smegma and the disinclination of many men to wash.

It is legitimate, indeed probably necessary, that a novel which takes rape as its subject makes no attempt to understand it in the sense of providing empathy with the rapist as well as with the victim; it is rather more doubtful whether it is a good idea for a study of rape, particularly 
one which makes extraliterary claim to experiential authority, to be so entirely without an analysis of what rape is, and the complexities of the ideology which serves it, an ideology which regularly sees potential victims as deserving of punishment.

It is interesting, however, how much that ideology permeates some of the novel's implied attitudes. Andrea talks of rape, particularly of the rape of children, as something which it is impossible that the victim can survive whole; she argues that most women with asthma are reliving paternal oral rape endlessly. To say that to be victimized once is thereafter to take your core identity from that victimization is perilously close to those patriarchal ideologies which kill rape victims as damaged goods. When Andrea talks of sex workers, it is in terms which animalize them; they are 'mules' and 'jackasses'. It is not always clear that it is their employers alone with whom she is angry; her language talks of the way they have been made, by pornographers, into objects, but does so in a way that fails to restore their humanity. The exception is Linda Marchiano, of course, whom she sees as a mystical sister, but then Linda Marchiano is the brand plucked from the burning.

Part of the purpose of this book must be, by describing rape in its various forms, to enhance the insight of Dworkin's previous book Intercourse that heterosexual, and, implicitly, penetrative, intercourse of all kinds is an untenable practice for women in a sexist society, that consent is impossible. The refusal to write in particularly evocative terms about bodily functions means that this argument is not made especially effectively; Dworkin does not appeal to common experience of the occasional awfulness of sex, which runs the risk of reminding how it can also occasionally be pleasurable, in specifics, but to a ritualized abstraction from experience. It is important not to eroticize rape, but, in a society where it is legitimized, it is also important to concretize its offensive assault on human decency.

This of course tallies with the aesthetic practice implicit in the Dworkin-McKinnon ordnance; if Dworkin disapproves of most forms of sexually explicit representation, she cannot represent graphically sexual activity of which she disapproves even to make us recognize that we share her disapproval. Much of the ultimate weakness of this ambitious book derives from the fact that Dworkin's own positions on representation make it impossible for her to achieve her artistic and political ends by accurate simple representation rather than rhetoric and manipulation.

The real failure of this book though is not in the cheating, or the calculated omissions, or the implicit élitism; it is in the deep solipsism that characterizes it from beginning to end. Dworkin rightly mocks male writers like Norman Mailer for trying to conquer the universe by an act of egotistical will, but the list of male greats at whom she sneers indicates that she sees herself as in some sort of competition with them. This is a book in which, from the beginning to the end of the main text, there is not a single other developed character.

The male characters are plot functions, who appear, rape the 
protagonist and depart, while all of the women from mother to friends, with a couple of momentary exceptions - Marchiano and a friendly lesbian hooker in a gold lamé dress - are shadows who fail to protect Andrea. This is a book which preaches solidarity between women, but represents a lone individual's struggle against an unfriendly universe, a woman of sorrows and acquainted with grief. It is this self-regarding and self-constructed figure that calls women together in a crusade of pointless retributive violence; the worth of the crusade as an egalitarian project can best be demonstrated by the way that Dworkin describes other women in the text, and the contemptuous way she endeavours to manipulate her women readers with rhetorical trickery.

\section{Notes}

Roz Kaveney is a journalist and a publishers' reader, living in London.

1 Note, for example, the suppression in the UK of Kathy Acker's short story collection Young Lust. Acker regularly uses cut-up techniques, and the UK publisher of one of her sources demanded the book's withdrawal on the grounds of breach of copyright. Her feminist publisher was obliged by its mainstream owner to comply. This suppression took place almost entirely without public comment or protest.

2 With the sole rivalry, perhaps, of the imputation to the novel's straw-woman lesbian-SM, deconstructionist academic of the view that the physical labour of the camps was good training for those survivors that made it through to become Zionist settlers; if at times the present piece seems hostile in its pronouncements, Dworkin's own courtesy in intra-feminist polemic itself lacks something, namely existence. 